No. 4 (1951). A pilot run to establish the conditions of the test has been successfully conducted on approximately 10 instruments of 5 different makes. It is hoped that as many separate examples of all commercially available instruments can be included in the full-scale test, which it is expected will be initiated in October of this year. Sample solutions will be supplied to those who agree to enter the test and they will be asked to run spectra $(a)$ under predetermined instrumental conditions, $(b)$ under their own preferred conditions. The analysis of the results of the test will be published in the Bulletin. Anyone who would like to enter a recording ultra-violet instrument should write to the honorary secretary, K. A. Macdonald, Unicam Instruments, Ltd., Arbury Works, Cambridge.

\section{The Devon Naturalists Trust}

A BODy, to be known as the Devon Naturalists Trust, has been formed with the support of many national and local bodies including the Nature Conservancy, the Council for Nature and the Devonshire Association. Lord Roborough is to be president of the Trust, and Mr. H. G. Hurrell chairman of its executive committee. The aims of the Trust are to protect places of interest to naturalists, to preserve the county's wild-life against encroachment, and to encourage the study of natural history. These aims should appeal to many who are concerned at the tide of change that has already much reduced the natural amenities of other counties, and is beginning to do so in Devon, too. It will be one of the main concerns of the Trust to see that developments of this sort are kept under constant review. There will be as meeting in Exeter to invite support and to publicize the Trust on May 16. Further information can be obtained from the honorary secretary, C. P. E. Grant, Chain House, Modbury, Ivybridge, Devon.

\section{Grants for Field Work in Natural History}

AT the suggestion of the Council for Nature, the Carnegie United Kingdom Trust has set aside a fund from whch it will make grants to approved societies for assistance with field work. These grants will be made on recommendations submitted by the Council for Nature, and will be contributions towards expenditure incurred in carrying out specific projects that give amateurs experience of field work in natural history under skilled direction. Approved expenditure is likely to include fees paid to experts for instruction and leadership, the incidental expenses of such people and the cost of essential equipment subject to certain conditions. Grants will not be available for the expenses incurred by members of the societies taking part in any scheme or for the general support of a society. Full particulars of the conditions for the award of grants can be obtained from the Council for Nature, 41 Queen's Gate, London, S.W.7.

\section{Library of Recorded Animal Sounds}

A LIBRARY of recorded animal sounds is being set up by the Committee for Biological Acoustics in collaboration with the British Institute of Recorded Sound, 38 Russell Square, London, W.C.1, in the archives of which the records will be stcred. The records will be made on magnetic tape and recorded at a standard speed of $7 \frac{1}{2}$ in. per sec.; each record will contain a commentary giving physical and biological data in relation to the recording. The recordings will be available free on loan to bona fide research workers anywhere in the world and the only expenses will be postage of the tapes. The library is being supported by a grant for equipment from the Royal Society. As soon as a reasonable number of recordings have been amassed a catalogue will be prepared and sent free of charge to all interested workers, departments and institutions. It is hoped that all workers in the field will give their support to the project, and those willing to allow their recordings to be copied for the library are asked to write to Dr. P. T. Haskell, Committee for Biological Acoustics, c/o Anti-Locust Research Centre, 1, Princes Gate, Kensington, London, S.W.7.

\section{Japan Association for Study of Congenital Anom- alies}

THE Japan Association for Study of Congenital Anomalies held its initial meeting at the Kyoto University, Faculty of Medicine, on February 25, 1961. For the time being, the Association has been established on an informal basis, by an organizing group consisting of the following members: Prof. Chisato Araki (Kyoto University); Prof. Tameyoshi Baba (Osaka Municipal University); Prof. Ichiro Hayashi (Nagasaki University); Prof. Yoshiki Mikami (Mie Prefectural University); Shigeru Mitani (Tokyo Women's Medical College); Prof. Ujihiro Murakami (Nagoya University); Prof. Hideo Nishimura (Kyoto University). Prof. Nishimura and a member of the organizing group will be in charge of international affairs.

\section{Association of Consulting Scientists}

AT the annual general meeting of the Association of Consulting Scientists, held in London recently, the following honorary officers and members of council were elected: chairman, Dr. M. Barent (Barent and Johnson); vice-chairman, Mr. F. G. Sarel Whitfield (Avebury Research Laboratories, Ltd.); honorary treasurer, Dr. G. W. Ferguson (Parry and Ferguson); honorary secretary, Mr. W. H. Stevens (W. H. Stevens); members of council, Dr. H. H. Chambers (Sondes Place Research Laboratories, Ltd.), Dr. J. G. Davis (Dr. J. G. Davis and Partners), Dr. Julius Grant (Hehner and Cox, Ltd.), Dr. R. F. Milton (R. F. Milton), Mr. O. W. Roskill (O. W. Roskill).

\section{Waverley Gold Medal Essay Competition}

The Waverley Gold Medal essay competition is sponsored by Research to encourage scientists to write clearly and comprehensibly about their work. The Medal, together with $£ 100$, will be awarded for the best essay of about 3,000 words describing a new project or practical development in pure or applied science, giving an outline of the scientific background, the experimental basis and the potential or actual application of the idea to industry or its importance to society. A second prize of $£ 50$ will be awarded and also a special prize of $£ 50$ for the best entry from a competitor under the age of thirty on July 31. Entry forms and further information can be obtained from the Editor of Research, 88 Kingsway, London, W.C.2. The last date of entry is July 31.

\section{Film-Strips on Physical Science}

A CLASSIFIED list of their film-strips and wallcharts in physics, chemistry and general science has been issued by Educational Productions, Ltd., of East Ardsley, Wakefield, Yorks. The strips deal with such topics as the structure of matter, electricity and light, while there is also a whole series of wall. 